\title{
Effective Labor Taxation and the International Location of Headquarters
}

\section{Journal Article}

\section{Author(s):}

Egger, Peter; Radulescu, Doina M.; Strecker, Nora (1)

Publication date:

2013-08

Permanent link:

https://doi.org/10.3929/ethz-b-000077331

Rights / license:

In Copyright - Non-Commercial Use Permitted

Originally published in:

International Tax and Public Finance 20(4), https://doi.org/10.1007/s10797-013-9288-6 


\title{
Effective labor taxation and the international location of headquarters
}

\author{
Peter Egger • Doina Radulescu • Nora Strecker
}

Published online: 4 July 2013

(C) Springer Science+Business Media New York 2013

\begin{abstract}
Profit taxes are widely acknowledged to influence the location of firms' headquarters. This paper sheds light on the role of aspects of labor taxation for the international location of headquarters. While profit taxes can be avoided in various ways, it is much harder for firms to manipulate the firm-specific labor tax base so that labor taxes may be relatively important for firm location. We construct a unique data set of effective labor taxes in 120 countries and use data on the location of 35,206 firms to analyze the impact of labor income tax rates, the progressivity of the income tax schedule, and social security contributions on firms' decisions where to locate their headquarters. The findings suggest that both a higher progressivity of the tax system and higher (employee- and employer-borne) social security contributions
\end{abstract}

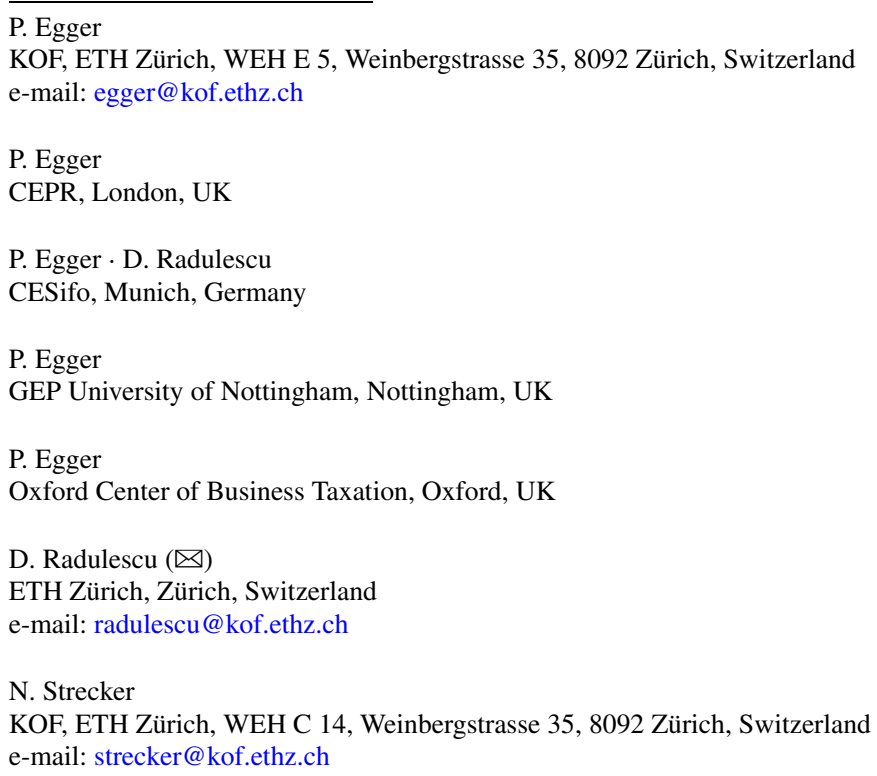


negatively influence a country's attractiveness for headquarters location. Hence, a one percentage point increase in these payroll taxes, reduces the probability of a country to attract headquarters by $6.1 \%$. The results prove robust in various empirical model specifications and subsets of the data.

Keywords Labor taxation · Headquarters · Location choice $\cdot$ Nested logit

\section{JEL Classification $\mathrm{H} 24 \cdot \mathrm{C} 25$}

\section{Introduction}

The taxation of profits and capital as an impediment to the location (and extent) of investment received much attention in theoretical as well as empirical academic work in public finance (see, e.g., Devereux and Griffith 1998; Devereux and Hubbard 2003). The focus on profit taxation flows from the assumption of capital to be relatively mobile across international borders, at least in comparison to other production factors such as labor. Empirical work, however, points to three issues suggesting that an emphasis on profit taxation may be insufficient: (i) capital and skilled workers have been conjectured and found to be largely complementary in production (see Griliches 1969; Duffy et al. 2004); (ii) skilled workers and employees - such as managers, technicians, and researchers-are relatively mobile across international borders (see Chiswick 1999; Liebig and Sousa-Poza 2004; Grogger and Hanson 2008); and (iii) the profit tax base can easily be manipulated (by transfer pricing, debt shifting, etc. ${ }^{1}$ while this is much harder for the labor (or income) tax base. Hence, income taxation may be relevant for headquarters location to the extent that it affects the local availability of skilled workers (and their effort) and even education choice of individuals in the long run.

There is anecdotal evidence that the (re)location of headquarters of large multinational firms in recent years has been codetermined by issues of profit and labor taxation. ${ }^{2}$ Most of the theoretical and empirical literature on the location of firms considers (employee- and employer-borne) income tax aspects only implicitly. ${ }^{3}$ If

\footnotetext{
${ }^{1}$ There is extensive evidence in the literature on the strategies and the extent to which multinational enterprises engage in profit shifting activities (see, for instance, Huizinga and Laeven 2008; Weichenrieder 2009). This can be done for instance by manipulating transfer prices (see Hines and Rice 1994; Clausing 2003), by intracompany loans (see, e.g., Mintz and Smart 2004; Büttner and Wamser 2007) or by the relocation of intangible assets to low-tax affiliates (see, e.g., Dischinger and Riedel 2011).

${ }^{2}$ For example, this was mentioned with regard to the relocation of the European headquarters of Procter and Gamble, McDonalds, and Kraft, from London to Switzerland (see Handelsblatt 2009).

${ }^{3}$ See Baldwin et al. (2003) for economic theory and Rathelot and Sillard (2008) for empirical analysis on the location of mobile firms in general; Markusen (2002) for economic theory and Strauss-Kahn and Vives (2009) for empirical analysis on the location of headquarters of multinational firms; Barba Navaretti and Venables (2006) for economic theory and Head and Mayer (2004) as well as Becker et al. (2005) for empirical analysis on the location of production units of multinational firms.

Defever (2006) focuses on the co-location of non-European firms' value chain in the European Union for the period 1997-2002 and finds that the location of service activities depends in particular on functional aspects and that headquarters location does not seem to attract any other part of a firm's value chain. Bel
} 
at all, previous work on firm location considered the role of profit taxation, but abstained from explicitly shedding light on income taxation issues. The paper by Egger and Radulescu (2011) is an exception. It considers the effects of labor taxation on bilateral foreign direct investment (FDI) in a cross section of 52 countries rather than headquarters location as such. Their results suggest that bilateral outward FDI is smaller the bigger the difference between host-to-parent country labor tax rates. The roles played by the net wage, the income tax rate, and, more generally, the employee's income tax burden, as opposed to the employer's tax burden, in determining firm locations are virtually unexplored. ${ }^{4}$

We argue that a higher employer-borne income tax burden on high-skilled labor directly reduces a firm's profits, as they represent a direct cost for the firm unless the tax burden can be fully passed on to employees. A higher employee-borne income tax burden exercises a negative effect on managerial effort (see Egger and Radulescu 2011) and, hence, indirectly reduces a firm's profits. ${ }^{5}$ Headquarters services intensively use high-skilled labor, in particular (see Carr et al. 2001; Markusen

and Fageda (2008) employ firm-level and international flights data on major urban areas in 25 European Union member countries. Their findings indicate that, among others, the proximity to large markets and the supply of direct international flights influence the headquarters location choice positively. Davis and Henderson (2008) use panel data on auxiliary establishments of firms in the United States and show that a higher number of local service input providers and the scale of other headquarters activities nearby stimulates the agglomeration of headquarters. Strauss-Kahn and Vives (2009) investigate the location of headquarters for the United States over the years 1996 to 2001 and find that factors such as low average wages, low corporate tax rates, and the agglomeration of other headquarters in the same sector influence the relocation of headquarters positively.

${ }^{4}$ As said before, this may be problematic especially, with an interplay of capital-skill complementarity at the headquarters level, the relative mobility of skilled workers, and the relative difficulty of avoiding labor taxes (relative to profit taxes).

${ }^{5}$ In economic theory, a salient prediction states that the effective economic incidence of a tax is independent of the statutory incidence of taxes. In our context, this implies that placing an income tax of the same amount on employees versus employers will have identical effects on the real economy, unless there are other distortions which cause asymmetric effects. This principle is referred to as "Invariance of Incidence Proposition (IIP)," and, for labor taxation, it inter alia requires perfectly competitive labor markets (OECD 1990). In the presence of adjustment costs or imperfect labor markets, moving from taxing income at the employer to taxing it at the employee may not be neutral. The labor market institutions and conditions have thus an important influence on the effect of different labor taxes. In reality, nominal contractual wages are characterized by a downward rigidity and prices (and real wages) are sticky (OECD 1990; Goerke 2000). At least in the short run, switching from employee to employer based income taxes increases wage cost to the employer and, unless the firm can charge higher prices or pass the costs on to the employee, will face a decline in profits (Rutkowski and Walewski 2007; Daveri and Tabellini 2000). In case of a "real wage resistance," a shift in personal income taxes or social security contributions induces a change in wage costs and taxes are (mainly or partly) borne by the firm, depending on the elasticity of labor supply. Daveri and Tabellini (2000) used data for continental European countries, to provide some evidence of wage resistance and found that a 10 percentage point increase in the tax wedge raises real labor costs by $5 \%$. Kugler and Kugler (2009) used a panel of manufacturing plants from Colombia over the 1980 s and 1990s and showed that wages fell only by 1.4 to $2.3 \%$ in response to a $10 \%$ rise in payroll taxes due to downward wage rigidities and an elastic labor supply in the Colombian labor market. Furthermore, as pointed out by Alesina and Perotti (1994), changes in the tax burden that induce a change in real labor costs can change domestic production costs vis-à-vis those of foreign competitors, and hence, indirectly influence labor demand. Thus, an increase in employer social security contributions can diminish a country's international competitiveness acting like a real exchange rate appreciation (Arpaia and Carone 2004). All of the just-mentioned arguments suggest a stronger effect of payroll taxes relative to labor income taxes on the location of firms. 


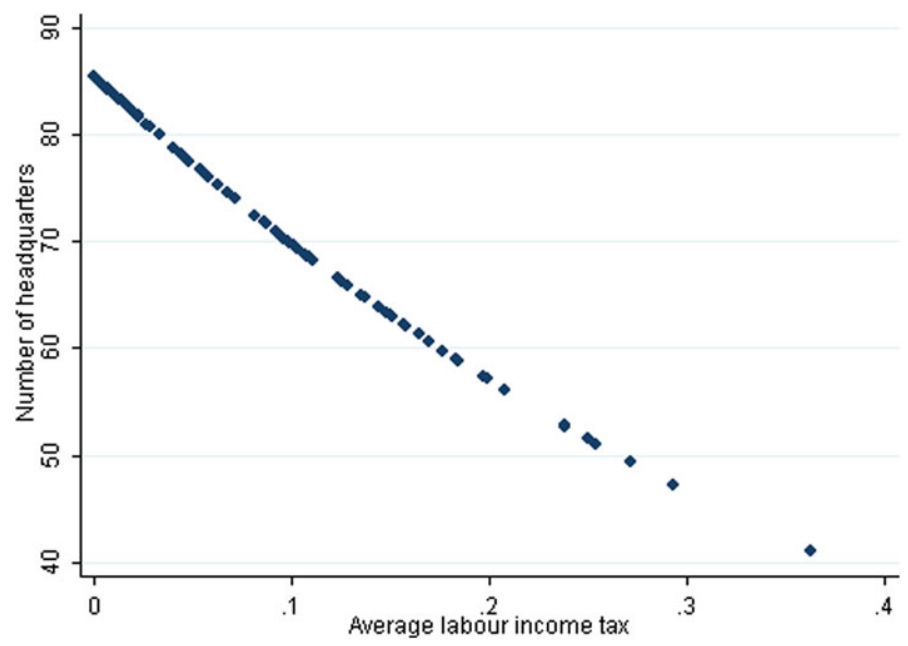

Note: The graph is based on a Poisson regression including as explanatory variables all controls of the conditional logit regression as explained in Sect. 3. The data on the number of headquarters comes from Compustat whereas the effective average labor income taxes are based on own calculations (see the description in Sect. 2).

Fig. 1 Predicted number of headquarters vs. average labor income tax

2002). High-skilled workers perform more complex tasks where outcome may be more risky and effort less observable than for more standardized low-skill-intensive activities. This suggests that the effort of high-skilled individuals may be more sensitive with respect to labor taxation than that of low-skilled workers. In addition, since high-skilled individuals tend to be more mobile across borders than low-skilled workers, labor taxation and the progressivity of a tax system will have a stronger negative effect on the availability of these individuals. Hence, the level of social security contributions and the level of income tax rates, as well as their progressivity should be important for a country's attractiveness as headquarters' location. The relationship between the number of headquarters and the labor income tax for an individual earning the average wage is depicted in Fig. 1. Accordingly, the figure shows that the predicted number of headquarters ceteris paribus declines with a higher labor income tax. The present paper assesses these previously mentioned hypotheses in the following way.

We construct a unique panel data set on average and marginal effective labor income taxes (including employee- and employer-borne social security contributions, tax credits, and tax allowances and deductions) for 120 economies. We exploit the cross-sectional dimension of this data-set by considering all location decisions or relocating and new (first) location. We match this data-set onto the universe of corresponding cross-sectional data on 37,502 firms from Compustat. This leads to a common data set of 79 countries and 35,206 firms, which can be used for the empirical analysis. Alternatively, we exploit information on new (first) locations and on relocations. 
The empirical results suggest that-conditional on other factors of influence such as profit taxes - the probability of a country to be chosen as the headquarters location depends negatively on the average level and progressivity of a country's income tax rate, as well as on the extent of social security contributions paid by firms and employees, respectively. The results are most pronounced for employer-borne payroll taxes among all components of effective labor income taxes. On average, for new (first or re-) locations a one percentage point increase in a country's labor income tax rate reduces the probability of it to attract the headquarters of the average firm by $6.1 \%$ versus $6.8 \%$ for a one percentage point increase in employer social security contributions.

The remainder of the paper is structured as follows. In the next section, we present the data, in particular, on effective labor income tax rates. Section 3 introduces the econometric approach used for the empirical analysis-conditional logit and nested logit models. Section 4 summarizes the empirical results and the results of a series of robustness checks, and Sect. 5 concludes.

\section{Data}

In general, we use averaged data for explanatory variables for the period 2005-2009 or for 1992-2009, when considering new (first) and relocations. The dependent variable is a binary location choice indicator, which denotes either the location state as of 2009, for 35,206 companies, the relocations between 1992 and 2009 for 610 companies, or the first location as well as relocation decisions for 4,335 firms.

\subsection{Data on headquarters location}

Information on the location of firms' headquarters is available from Compustat. That data set provides the residence country of the headquarters (as opposed to the country of incorporation) of global firms, covered by stock indices. For each company, this allows us to determine the $J$-nomial variable $L o c$ and the binary variable $L o c_{i j}$, where the latter is unity whenever, for firm $i$ with $i=1, \ldots, I, L o c=j$ with $j=1, \ldots, J$ in 2009. Similarly, we can determine relocations between 1992 and 2009. Following the direction of Pastor and Veronesi (2003), Fama and French (2004), or Chun et al. (2008), we obtain our sample of first locating firms, by matching the date of the initial public offering of our firms to the time in which they first appear in our data set. If the IPO date ${ }^{6}$ occurred in the same (or later) year, we consider it a first locating firm. ${ }^{7}$

\subsection{Data on income taxation}

One contribution of this paper is the construction of a unique panel data set on effective labor income taxes for 120 countries annually for the years 1992-2009. We

\footnotetext{
${ }^{6}$ This information is only available for the North American data set.

${ }^{7}$ Notice that, with relocations or new locations, exploiting a short time period may be problematic for reasons of few events, especially, if the focus is on headquarters and large firms.
} 
follow the methodology of the "Taxing Wages" approach used by the OECD, discussed by Head and Mayer (2004) and described in Egger and Radulescu (2011), to compute marginal and average effective tax rates plus the social security contributions for an individual earning the average wage or five times the average wage of an economy. Beyond social security contributions, we account for detailed provisions of the respective national tax codes such as personal tax allowances, tax credits, standard deductions, other country-specific formulae, and local (subnational) taxes. ${ }^{8}$ This data set allows us to consider the importance of the progressivity of a country's income tax schedule beyond the one of average tax rates. The latter appears of particular importance when considering the role of income taxation for high-skilled (and hence, high-income) earners, as opposed to average workers and employees.

This comprehensive data set on income taxation was assembled from numerous sources such as individual countries' tax law, publications from international organizations, and data from international accounting firms. Among the most important sources, beyond individual countries' sources, we should mention the OECD (1990-2009) Taxing Wages data sets for several years, PricewaterhouseCoopers' (1997-2005) Individual Taxes: Worldwide Summaries and PricewaterhouseCoopers Worldwide Tax Summaries for various years, PKF International's (2007-2010) Worldwide Tax Guide, the legal database provided by the Global legal information network (1980-2012), the Social Security Observatory's (2002-2010) Social Security Programs Throughout the World for social security legislation, and the International Labor Organization's (ILO) LABORSTA database for data on annual gross wages.

Based on the aforementioned data sources, we define the following variables capturing aspects of the income taxation of country $j:$ LabTax $_{j}$ denotes the labor income tax burden on an individual earning the average wage; $\operatorname{Prog}_{500}{ }_{j}$ indicates the progression of a country's tax schedule defined as the log of one minus the difference between the marginal taxes of an individual earning five times the average wage and the marginal tax of an individual earning the average wage; EmployeeSocSec ${ }_{j}$ and EmployerSocSec ${ }_{j}$ represent employee- and employer-borne social security contributions, respectively. LabTax $500_{j}$ indicates the labor income tax burden for an individual earning five times of the average wage. ${ }^{9}$

To compute the above and the corresponding marginal income tax rates, we used information on average gross wages per employee in US dollars, Wage ${ }_{j}$, from the ILO's LABORSTA database. For consistency's sake, we used annual sectoral wages by level of employment to create an average annual wage where possible.

\subsection{Data on control variables}

Several control variables for headquarters location beyond income tax variables were based on source data from the World Bank's World Development Indicators and the

\footnotetext{
${ }^{8}$ Peter et al. (2010) compute the tax liability for pretax incomes equivalent to one, two, three and four times a country's GDP per capita. However, we assume gross wages to be better reflective of the actual income tax base. Also, Peter et al. (2010) do not account for social security contributions and other provisions, which we consider as important for inference of the effective tax burden on labor.

${ }^{9} \mathrm{~A}$ considerable number of countries have labor income, social security, and corporate income tax rates of zero.
} 
United Nations' Statistics Division. In particular, we used the following variables and data in all regressions: statutory corporate tax rates across potential locations $\left(\operatorname{CorpTax}_{j}\right)$ as a fraction of unity, measuring the intensity of profit taxation; gross domestic product in US dollars as a measure of $j$ 's market size $\left(G D P_{j}\right)$; a country's capital stock in US dollars ( CapStock $_{j}$ ) as a measure of capital abundance (given market size $) ;{ }^{10}$ and on average wages per employee in US dollars (Wage ${ }_{j}$ ) as a measure of wage costs in $j$ net of labor taxes. While data on the latter variable come from the ILO LABORSTA database, the ones underlying $\operatorname{CorpTax}_{j}, G D P_{j}$, and CapStock $_{j}$ are from the World Bank's World Development Indicators. Moreover, in some regressions we use the share of the population with tertiary education in country $j$ $\left(T e r t E d u_{j}\right)$ based on data from Lutz (2007) to measure skill abundance, ${ }^{11}$ and the number of flights to and from country $j$ as a measure of infrastructure abundance to construct the following variables (Flights $_{j}$ ) from World Development Indicators. To include a measure of the institutional strength of a country, we employ an indicator LegalRights $\left._{j}\right)$, which is unity if the country's legal rights index, as reported in the World Development Indicators, is above the world-wide median. ${ }^{12}$ All remaining variables are used in a log-transformed way. In particular, all income and profit tax measures are log-transformed after subtracting the respective fraction from unity (since some of those measures are zero). Hence, the respective variables measure a country's attractiveness in (income and profit) tax terms. All level variables enter the regressions simply in a log-transformed way, except for TertEdu $u_{j}$ which is the log of the tertiary education share plus unity.

\subsection{Descriptive statistics}

Table 1 provides summary statistics of the data for 79 countries and 35,206 firms for which all the necessary information is available and which can subsequently be used for the empirical analysis.

Table 1 suggests that the mean of the labor tax burden on an individual earning the average wage is $10.3 \%$ and the maximum is $36.3 \%$ for the average country

\footnotetext{
${ }^{10}$ We follow Griliches (1980) to use the perpetual inventory method for calculating country-specific capital stocks. The capital stock of country $j$ in year $t$ is

$$
K_{j t}=K_{j t-1}(1-\delta)+I_{j t},
$$

where $I_{j t}$ is real investment (gross fixed capital formation in constant US dollars of the year 2000) in country $j$ and year $t$ and $\delta$ denotes the depreciation rate, which we assume to be $10 \%$. The capital stock $K_{j 0}$ in the first period of the sample is computed as

$$
K_{j 0}=\frac{I_{j 0}}{\left(g_{j}^{-}+\delta\right)},
$$

where $\bar{g}_{j}$ represents the average annual investment growth rate over the whole time span and $I_{j 0}$ denotes investment in the first year where data are available. We then calculate the average value of $K_{j t}$ for the relevant time span (2005-2009 or 1992-2009).

${ }^{11}$ We argue that strong progressivity of the income tax system may distort the education decision of individuals. To that end, the tertiary education measure may reflect in part an income tax effect. However, income taxation should also induce an impact on effort beyond education.

${ }^{12}$ The worldwide median for the WDI's Strength of Legal Rights Index is 6 out of a possible 10.
} 
Table 1 Summary statistics for stock of firms: 2005-2009

\begin{tabular}{lllllll}
\hline & Mean & Stddev & Median & Max & Min & Nb-obs \\
\cline { 2 - 7 } & $(1)$ & $(2)$ & $(3)$ & $(4)$ & $(5)$ & $(6)$ \\
\hline LabTax & 0.103 & 0.071 & 0.108 & 0.363 & 0.000 & 35,206 \\
Prog500 & 0.155 & 0.071 & 0.143 & 0.432 & 0.000 & 35,206 \\
EmployerSocSec & 0.110 & 0.065 & 0.095 & 0.372 & 0.000 & 35,206 \\
EmployeeSocSec & 0.075 & 0.048 & 0.071 & 0.300 & 0.000 & 35,206 \\
CorpTax & 0.324 & 0.067 & 0.331 & 0.411 & 0.000 & 35,206 \\
GDP, mn. US\$ & $3,884,000$ & $4,688,000$ & $2,470,000$ & $13,720,000$ & 3,418 & 35,206 \\
CapStock, mn. US\$ & $5,283,000$ & $5,862,000$ & $2,640,000$ & $16,410,000$ & 8,060 & 35,206 \\
TertEdu & 0.589 & 0.131 & 0.588 & 0.858 & 0.167 & 35,206 \\
Wage & 34,386 & 18,103 & 40,135 & 66,851 & 20 & 35,206 \\
\hline
\end{tabular}

Table 2 Summary statistics for relocating \& first locating firms: 1992-2009

\begin{tabular}{lllllll}
\hline & Mean & Stddev & Median & Max & Min & Nb-obs \\
\cline { 2 - 7 } & $(1)$ & $(2)$ & $(3)$ & $(4)$ & $(5)$ & $(6)$ \\
\hline LabTax & 0.148 & 0.053 & 0.170 & 0.400 & 0.000 & 4,335 \\
Prog500 & 0.104 & 0.040 & 0.092 & 0.365 & 0.000 & 4,335 \\
EmployerSocSec & 0.094 & 0.045 & 0.079 & 0.282 & 0.000 & 4,335 \\
EmployeeSocSec & 0.072 & 0.026 & 0.070 & 0.258 & 0.000 & 4,335 \\
CorpTax & 0.377 & 0.052 & 0.393 & 0.456 & 0.000 & 4,335 \\
GDP, mn. US\$ & $7,582,000$ & $3,979,000$ & $10,150,000$ & $10,150,000$ & 5,016 & 4,335 \\
CapStock, mn. US\$ & $9,061,000$ & $4,420,000$ & $11,750,000$ & $11,750,000$ & 6,281 & 4,335 \\
TertEdu & 0.679 & 0.089 & 0.725 & 0.868 & 0.233 & 4,335 \\
Wage & 35,630 & 10,760 & 40,020 & 70,343 & 635 & 4,335 \\
\hline
\end{tabular}

and year between 2005 and 2009. The average rate of progressivity is $15.5 \%$ and has a maximum value of $43.2 \%$ in that period. The average values of employerborne and employee-borne social security contributions amount to $11 \%$ and $7.5 \%$, respectively, with maximum values of $37.2 \%$ and $30 \%$, respectively. Table 1 also reports summary statistics on corporate taxes, which range from a minimum value of $0 \%$ to a maximum of $41.1 \%$ with an average value of $32.4 \%$. The lowest average annual wage income amounts to 20 US dollars recorded in Zimbabwe and the highest one to 66,851 US dollars recorded in Switzerland.

In Table 2, we present the same summary statistics but this time for a smaller sample of 50 countries and 4,335 firms including only the relocated and first locating firms. The mean for the labor tax burden for an individual earning the average wage amounts to $14.8 \%$, with a maximum of $40 \%$ for the average country between 1992 and 2009. Progressivity amounts to slightly more than $10 \%$, with a maximum of $36.5 \%$. Social security contributions remained roughly on par with the sample for 2005-2009. Corporate taxes now range from $0 \%$ to $45.6 \%$ with an average of $37.7 \%$. 
Fig. 2 Conditional logit choice structure

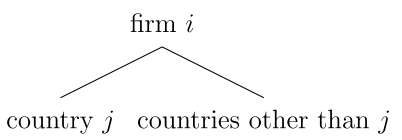

\section{Empirical strategy}

This section introduces the empirical specifications used to identify whether and to which extent labor taxes, social security contributions, and the progressivity of a tax system ceteris paribus play a role in a firm's decision about where to locate its headquarters.

\subsection{Conditional logit}

To estimate location choice behavior, one model is the conditional logit model (McFadden 1974), as illustrated in Fig. 2. This model is suitable to address the question of how a country's characteristics, such as the effective taxes on labor income, affect a country's likelihood of being chosen as a firm's headquarters location.

As explained in Sect. 2.1, we denote the binary dependent variable by $L o c_{i j}$. It is unity if firm $i=1, \ldots, I$ has its headquarters in country $j=1, \ldots, J$ in 2009 and zero otherwise. Alternatively, it is unity if firm $i$ relocates or locates for the first time its headquarters in $j$ between 1992 and 2009, and zero otherwise. To determine the probability that country $j$ is chosen as the location of firm $i$ 's headquarters, we first define the deterministic net return that would be derived from locating in country $j$ as

$$
V_{i j}=V\left(L_{o c} i_{j}=1 \mid x_{j}\right)=\beta x_{j}^{\prime},
$$

where $x_{j}$ denotes a vector of alternative-specific variables facing the headquarters of firm $i$ in country $j$, such as LabTax $_{j}$, Prog $500_{j}$, EmployeeSocSec $_{j}$, EmployerSocSec $_{j}$, CorpTax $_{j}, G P_{j}$, CapStock $_{j}$, Wage ${ }_{j}$, TertEdu $_{j}$, Flights $_{j}$, and LegalRights ${ }_{j}$.

The conditional probability of headquarters location for firm $i$ in country $j$ is first estimated using the following conditional logit regression model ${ }^{13}$

$$
\operatorname{Pr}\left(\operatorname{Loc}_{i j}=1 \mid x_{j}\right)=\frac{e^{V_{i j}}}{\sum_{l=1}^{J} e^{V_{i l}}}=\frac{e^{\beta x_{j}^{\prime}}}{\sum_{l=1}^{J} e^{\beta x_{l}^{\prime}}}, \quad \forall l=1, \ldots, J: j \neq l .
$$

As is well known, $\beta$ can be estimated consistently if the following assumptions hold: First, error terms associated with the stochastic version of (3) must be identically and independently distributed, and second, the independence of irrelevant alternatives (IIA) criterion must be met. If the IIA assumption is violated, including some

\footnotetext{
${ }^{13}$ Notice that the conditional logit model is also dubbed the conditional fixed effect logit model as it captures by construction all characteristics that are invariant across locations and specific to the individual or firm making location choices (see Allison 2009; Greene 2002). Since a firm's main industry is a (fairly) time-invariant characteristic, the approach implicitly also controls for product characteristics. However, this is not the case with regional-specific effects, which vary across nests of locations $j$. The latter may be accounted for in a nested logit model using, e.g., continental clustering.
} 


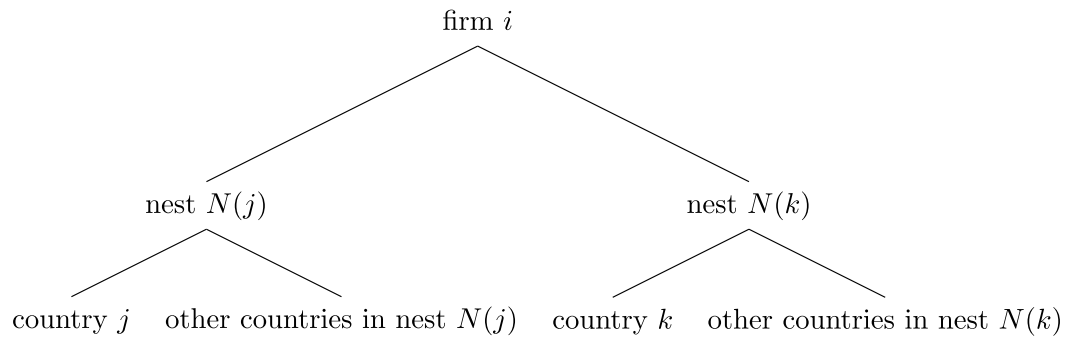

Fig. 3 Nested logit choice structure

previously omitted location could alter the probability at which similar countries are chosen. For example, exclusion of Canada from the list of alternative countries could increase the probability that firms locate in the United States. Similarly, Germany and France could have correlated error terms, both being in Europe. Such correlation is ruled out under IIA; therefore, the conditional logit model runs the risk to produce biased estimates of the effects of taxes on the location decision.

\subsection{Nested logit}

To overcome the potential bias of the conditional logit model following from a violation of the IIA assumption, we employ the nested logit model as an alternative econometric approach, because it relaxes the IIA criterion by employing a hierarchical choice structure. In the nested logit model, we group countries by per-capita income (low, middle-low, middle-high, and high) following the World Bank's categorization with the first two groups combined into one so as to achieve a more even distribution of countries into nests. ${ }^{14}$ The decision to locate in country $j$ is split into first the choice of the nest of countries $j$ belongs in, $N(j)$, which is determined by nest-specific characteristics that do not vary within the nest, and, subsequently, the choice among the countries within the nest, as illustrated in Fig. 3.

The deterministic net return of firm $i$ from locating its headquarters in country $j$ is then specified as

$$
V_{i j}=V\left(\operatorname{Loc}_{i j}=1 \mid x_{j}, w_{n}\right)=\beta x_{j}^{\prime}+\delta_{n} w_{n}^{\prime},
$$

\footnotetext{
${ }^{14}$ Of the 79 countries in our sample, 37 fall into the high-income category, 25 into the middle-high income class, 17 middle-low to low-income countries. The exact definition is as follows. High-income countries: Austria, Australia, the Bahamas, Bahrain, Belgium, Canada, Croatia, Cyprus, Czech Republic, Denmark, Estonia, Finland, France, Germany, Great Britain, Greece, Hong Kong, Hungary, Ireland, Italy, Japan, Luxembourg, Malta, the Netherlands, Norway, New Zealand, Poland, Portugal, Saudi Arabia, Singapore, Slovak Republic, Slovenia, South Korea, Spain, Sweden, Switzerland, and the United States. Middle-to-high-income countries: Argentina, Bulgaria, Brazil, Chile, China, Colombia, Costa Rica, Dominican Republic, Ecuador, Gabon, Jordan, Kazakhstan, Lithuania, Latvia, Mexico, Mauritius, Malaysia, Namibia, Panama, Peru, Romania, Russia, South Africa, Thailand, and Turkey. Low-income countries: Bangladesh, Bolivia, Cote d'Ivoire, Egypt, Ghana, India, Indonesia, Kenya, Morocco, Pakistan, Paraguay, the Philippines, Sri Lanka, Ukraine, Vietnam, Zambia, and Zimbabwe. From here on, we will refer to the middle-to-high-income category as the middle-income category.
} 
where $x_{j}$ is a vector of alternative-specific variables firm $i$ faces in country $j$, and $w_{n}$ denotes a vector of nest-specific variables determining the choice of nest $N(j){ }^{15}$

The probability of locating in country $j$ can be split into the product of the conditional probability of locating in country $j$ if it belongs in nest $N(j)$-term (a) - and the probability of $j$ being in nest $N(j)$ —term (b):

$$
\operatorname{Pr}\left(L_{i j}=1 \mid x_{j}\right)=\underbrace{\operatorname{Pr}\left(L o c_{i j}=1 \mid x_{j} \in N(j)\right)}_{(a)} \times \underbrace{\operatorname{Pr}(j \in N(j))}_{(b)} .
$$

(a)

Starting with term (a), we can describe the conditional probability of belonging in nest $N(j)$ as

$$
\operatorname{Pr}\left(\operatorname{Loc}_{i j}=1 \mid x_{j} \in N(j)\right)=\frac{e^{\frac{V_{i j}}{\tau_{N(j)}}}}{\sum_{l \in N(j)} e^{I V_{N(j)}}}, \quad \forall j \neq l \in N(j)
$$

where

$$
I V_{N(j)}=\ln \sum_{l \in N(j)} e^{\frac{V_{i j}}{\tau_{N(j)}}}
$$

The random net return maximization model adopted here imposes the least restrictions on the structure of the nested logit model and allows us to compare countries even across nests rather than only within a nest. In that model, the dissimilarity parameter, $\tau_{N(j)}$, is a measure of the uniqueness of the country-alternatives within nest $N(j)$ and is defined as

$$
\tau_{N(j)}=\sqrt{1-\rho_{N(j)}},
$$

where $\rho_{N(j)}$ denotes the correlation coefficient among the error terms within nest $N(j)$. If the correlation among countries within a nest is positive, then $\tau_{N(j)}$ will be within the unit interval. ${ }^{16}$

Term (b) in Eq. (6) represents the conditional probability of choosing country $j$ in nest $N(j)$ and can be expressed as

$$
\operatorname{Pr}(j \in N(j))=\frac{e^{\tau_{N(j)} I V_{N(j)}}}{\sum_{k \in N(k)} e^{\tau_{N(k)} I V_{N(k)}}}, \quad \forall N(j) \neq N(k)
$$

\footnotetext{
${ }^{15}$ In the generalized version, we set up the nested logit model such that the alternative-specific variables have a nonalternative-specific coefficient, while the nest-specific variables have nest-specific coefficients. We do this since alternative-specific variables will have an equal influence on firms, while the other variables are indeed nest-specific.

${ }^{16}$ It is possible that the correlation of countries within a nest is negative, resulting in a $\left|\tau_{N(j)}\right|>1$.
} 
By multiplying the two probabilities defined in Eqs. (7) and (10), we obtain the probability of choosing country $j$ as the headquarters location:

$$
\begin{aligned}
& \operatorname{Pr}\left(\operatorname{Loc}_{i j}=1 \mid x_{j}\right)=\frac{e^{\frac{V_{i j}}{\tau_{N(j)}}}}{\sum_{l \in N(j)} e^{\frac{V_{i l}}{\tau_{N(j)}}}} \times \frac{e^{\tau_{N(j)} I V_{N(j)}}}{\sum_{k \in N(k)} e^{\tau_{N(k)} I V_{N(k)}}}, \\
& \forall j \neq l \in N(j), N(j) \neq N(k) .
\end{aligned}
$$

By obtaining estimates for the $V_{i j}$ in the nested logit model, we can evaluate the probability of choosing country $j$ as a location of headquarters as well as semielasticities of tax parameters.

\section{Estimation results}

We hypothesize ceteris paribus a negative effect of our variables of interest-namely the ones involving LabTax ${ }_{j},{\text { Prog } 500_{j}, \text { EmployeeSocSec }_{j} \text {, and EmployerSocSec }}_{j}$ on a country's attractiveness as a potential headquarters location. Higher labor income taxes, higher employee-borne social security contributions and a more progressive tax system exert a negative effect on effort of high-income earners, such as managers and engineers, whereas higher employer-borne social security contributions represent higher direct labor costs for firms such that all four variables negatively affect expected profits, directly or indirectly. The effects of these variables of interest are estimated conditionally on a number of aforementioned control variables involv-

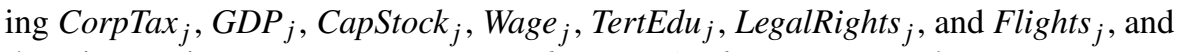
three interaction terms, Wage ${ }_{j} \times$ TertEdu $_{j}$, CapStock $_{j} \times G D P_{j}$, and Wage ${ }_{j} \times G D P_{j}$. These control variables account for determinants of headquarters location choice beyond labor taxes.

We rationalize the effects of these additional controls in the following way. Higher corporate taxes, CorpTax $_{j}$, and higher average gross wages, Wage ${ }_{j}$, should reduce a country's attractiveness as a potential location for headquarters since they both reduce profits ceteris paribus. ${ }^{17}$ In line with previous theoretical research, we expect that a higher $G D P_{j}$, as a measure of market size, positively influences the inclination of firms to locate in a particular country, the same goes for a bigger capital stock CapStock $_{j}$, which, given country size, is a proxy for the availability of capital in a country. Finally, a more educated population, TertEdu $u_{j}$, greater institutional quality, LegalRights ${ }_{j}$, as well as a better traffic and airport infrastructure, Flights ${ }_{j}$, for a given country size, should also increase a country's attractiveness as a potential host for headquarters at given country size. The interaction terms Wage ${ }_{j} \times$ TertEd $_{j}$, Wage $_{j} \times G D P_{j}$, and CapStock , $_{j} \times G D P_{j}$ control for a possibly lesser importance of wage costs in skill-abundant and large markets on the one hand and of market

\footnotetext{
${ }^{17}$ Given that the conditional logit model implicitly controls for company specific effects such as productivity, wage cost differences reflect production costs rather than productivity levels, such that we can safely assume a negative effect on profits.
} 
Table 3 Conditional logit results for country choice

\begin{tabular}{|c|c|c|c|}
\hline & Model & Model & Model \\
\hline & (1) & $(2)$ & (3) \\
\hline \multirow[t]{2}{*}{$\ln (1-$ LabTax $)$} & $1.730^{* * *}$ & $1.523^{* * *}$ & 0.263 \\
\hline & 0.109 & 0.153 & 0.167 \\
\hline \multirow[t]{2}{*}{$\ln (1-$ Prog 500$)$} & $0.598^{* * *}$ & $0.800^{* * *}$ & $1.205^{* * *}$ \\
\hline & 0.089 & 0.098 & 0.103 \\
\hline \multirow[t]{2}{*}{$\ln (1-$ EmployerSocSec $)$} & $5.202^{* * *}$ & $4.862^{* * *}$ & $5.116^{* * *}$ \\
\hline & 0.077 & 0.097 & 0.099 \\
\hline \multirow[t]{2}{*}{$\ln (1-$ EmployeeSocSec $)$} & $1.943^{* * *}$ & $2.027^{* * *}$ & -0.159 \\
\hline & 0.143 & 0.150 & 0.170 \\
\hline \multirow[t]{2}{*}{$\ln (1-$ CorpTax $)$} & $1.413^{* * *}$ & $0.740^{* * *}$ & $0.923^{* * *}$ \\
\hline & 0.076 & 0.124 & 0.125 \\
\hline \multirow[t]{2}{*}{$\ln (G D P)$} & $1.211^{* * *}$ & $1.465^{* * *}$ & $1.195^{* * *}$ \\
\hline & 0.066 & 0.081 & 0.082 \\
\hline \multirow[t]{2}{*}{$\ln ($ CapStock $)$} & $2.948^{* * *}$ & $2.486^{* * *}$ & $3.984^{* * *}$ \\
\hline & 0.080 & 0.092 & 0.116 \\
\hline \multirow[t]{2}{*}{$\ln ($ Wage $)$} & -0.004 & 0.148 & $-0.464^{* * *}$ \\
\hline & 0.127 & 0.138 & 0.141 \\
\hline \multirow[t]{2}{*}{$\ln ($ TertEdu $)$} & & $3.418^{* * *}$ & $5.296^{* * *}$ \\
\hline & & 0.215 & 0.225 \\
\hline \multirow[t]{2}{*}{ LegalRights } & & $0.591^{* * *}$ & $0.751^{* * *}$ \\
\hline & & 0.021 & 0.022 \\
\hline \multirow[t]{2}{*}{$\ln ($ Flights $)$} & & & $0.304^{* * *}$ \\
\hline & & & 0.014 \\
\hline \multirow[t]{2}{*}{$\ln ($ Wage $\times$ TertEdu $)$} & & $-0.385^{* * *}$ & $-0.604^{* * *}$ \\
\hline & & 0.022 & 0.024 \\
\hline \multirow[t]{2}{*}{$\ln ($ CapStock $\times G D P)$} & $-0.062^{* * *}$ & $-0.055^{* * *}$ & $-0.084^{* * *}$ \\
\hline & 0.005 & 0.003 & 0.003 \\
\hline \multirow[t]{2}{*}{$\ln ($ Wage $\times G D P)$} & $0.009^{*}$ & $0.010^{*}$ & 0.003 \\
\hline & 0.003 & 0.005 & 0.005 \\
\hline Cases & 35,840 & 35,206 & 34,302 \\
\hline LR & $90,832.95^{* * *}$ & $79,903.83^{* * *}$ & $77,758.29^{* * *}$ \\
\hline Pseudo- $R^{2}$ & 0.2763 & 0.2602 & 0.2647 \\
\hline
\end{tabular}

Notes: Choice of country using the conditional logit model. Standard errors are reported beneath the coefficients. The symbols ${ }^{* * *},{ }^{* *}$, and ${ }^{*}$ denote statistical significance at 1,5 , and $10 \%$, respectively.

size and capital-abundance (as a measure of development) on the other hand. Since

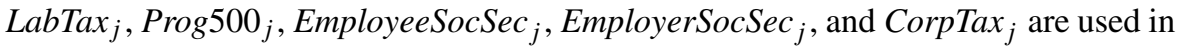
$\log$-transformed variables, the log of one minus the respective variable in our regressions, positive coefficients for the first five dependent variables reported in Tables 3, 
4 , and 6 actually reflect a negative impact of the underlying tax components on location choice, as seen by the negative semi-elasticities.

\subsection{Conditional logit estimates}

Table 3 presents the regression results for three alternative conditional logit specifications. The three specifications differ with respect to the control variables included. The coefficients of the main variables of interest, namely the ones involving LabTax ${ }_{j}$, ${\text { Prog } 500_{j}, \text { EmployeeSocSec }_{j} \text {, and EmployerSocSec }}_{j}$, are positive (i.e., the impact of the underlying tax instruments is negative) and highly significant in Models (1) and (2), while LabTax ${ }_{j}$ and EmployeeSocSec ${ }_{j}$ are not significantly different from zero in Model (3).

Headquarters location choice obviously depends on other factors beyond labor taxes. Capital abundance and market size display a positive effect on the decision to locate in a particular country, as expected. In Models (2) and (3), we also account for the influence of the population with tertiary education. The coefficient of interest is positive and highly significant. Moreover, a better airport infrastructure, as captured by the number of international flights, increases the probability of choosing a particular host country. The interaction terms of wages with $G D P_{j}$ and TertEdu are significantly different from zero while the main effect of wages is not. Many of the estimated parameters are significant at $1 \%$. We consider Model (2) as a reasonably parsimonious benchmark specification and consider modifications of it in what follows.

One particular concern with the results in Table 3 might be that there is enormous heterogeneity about the timing of location choice in the sample of firms at hand. In other words, it would be desirable to focus on new locations in comparison to all locations. We pursue such an approach in two ways. First, we consider relocations of headquarters in the time window 1992-2009. A relocation is identified by a firm identifier and a change in the country of location (domicile) of a headquarters. In the data, there are 610 relocations between 1992 and 2009. Alternatively, we may consider new locations in general, defined as relocations and first locations (through new incorporations). We do so by considering first locations and relocations between 1992 and 2009 in the data. Altogether, this obtains 4,335 new locations (first locations plus relocations). The corresponding parameter estimates are summarized in Table 4.

For convenience, Table 4 repeats the estimates for Model (2) from Table 3 in the first column. The parameters suggest that the results qualitatively support the conclusions drawn from Table 3, except for employee-borne social security contributions. However, we should be aware of the drastically smaller number of observations when considering location changes relative to the stock of locations in Table 3.

Since the models in Tables 3 and 4 are nonlinear, we cannot infer anything from the coefficient estimates about the relative importance of tax instruments in affecting location choice within and across the estimated models. To assess the relative importance of the variables of interest, we calculate semi-elasticities by raising one tax instrument's level by one percentage point (i.e., by 0.01) and assessing the change in the average probability of a country being chosen as the location in response to the 
Table 4 Baseline regression results: conditional logit model

\begin{tabular}{|c|c|c|c|}
\hline & Stock of firms & Relocating firms & Relocating \& new firms \\
\hline \multirow[t]{2}{*}{$\ln (1-$ LabTax $)$} & $1.523^{* * *}$ & $7.793^{* * *}$ & $5.721^{* * *}$ \\
\hline & 0.153 & 1.426 & 0.771 \\
\hline \multirow[t]{2}{*}{$\ln (1-$ Prog 500$)$} & $0.800^{* * *}$ & $6.209^{* * *}$ & $5.815^{* * *}$ \\
\hline & 0.098 & 1.180 & 0.575 \\
\hline \multirow[t]{2}{*}{$\ln (1-$ EmployerSocSec $)$} & $4.862^{* * *}$ & $11.306^{* * *}$ & $6.129^{* * *}$ \\
\hline & 0.097 & 1.415 & 0.724 \\
\hline \multirow[t]{2}{*}{$\ln (1-$ EmployeeSocSec $)$} & $2.027^{* * *}$ & $-3.454^{*}$ & $-2.139^{* *}$ \\
\hline & 0.150 & 1.895 & 1.047 \\
\hline \multirow{2}{*}{$\ln (1-\operatorname{CorpTax})$} & $0.740^{* * *}$ & $2.031^{* *}$ & $2.118^{* * *}$ \\
\hline & 0.124 & 0.856 & 0.542 \\
\hline \multirow[t]{2}{*}{$\ln (G D P)$} & $1.465^{* * *}$ & $9.177^{* * *}$ & $2.601^{* * *}$ \\
\hline & 0.081 & 1.114 & 0.492 \\
\hline \multirow[t]{2}{*}{$\ln ($ CapStock $)$} & $2.486^{* * *}$ & $-2.034^{* * *}$ & $-3.588^{* * *}$ \\
\hline & 0.092 & 0.711 & 0.390 \\
\hline \multirow[t]{2}{*}{$\ln ($ Wage $)$} & 0.148 & $11.750^{* * *}$ & $7.269^{* * *}$ \\
\hline & 0.138 & 1.600 & 0.877 \\
\hline \multirow[t]{2}{*}{$\ln ($ TertEdu $)$} & $3.418^{* * *}$ & $55.079^{* * *}$ & $18.403^{* * *}$ \\
\hline & 0.215 & 7.094 & 3.627 \\
\hline \multirow[t]{2}{*}{ LegalRights } & $0.591^{* * *}$ & $1.396^{* * *}$ & $0.765^{* * *}$ \\
\hline & 0.021 & 0.263 & 0.136 \\
\hline \multirow[t]{2}{*}{$\ln ($ Wage $\times$ TertEdu $)$} & $-0.385^{* * *}$ & $-4.967^{* * *}$ & $-1.576^{* * *}$ \\
\hline & 0.022 & 0.706 & 0.361 \\
\hline \multirow[t]{2}{*}{$\ln ($ CapStock $\times G D P)$} & $-0.055^{* * *}$ & $-0.045^{*}$ & $0.087^{* * *}$ \\
\hline & 0.003 & 0.026 & 0.013 \\
\hline \multirow[t]{2}{*}{$\ln ($ Wage $\times G D P)$} & $0.010^{*}$ & $-0.369^{* * *}$ & $-0.245^{* * *}$ \\
\hline & 0.005 & 0.054 & 0.031 \\
\hline Cases & 35,206 & 610 & 4,335 \\
\hline Log-likelihood & $-113,582.97$ & $-1,562.26$ & $-6,518.17$ \\
\hline LR & $79,903.88^{* * *}$ & $1,648.15^{* * *}$ & $20,893.86^{* * *}$ \\
\hline Pseudo- $R^{2}$ & 0.2602 & 0.3453 & 0.6158 \\
\hline
\end{tabular}

Notes: Representation of conditional logit results for the baseline Model (2) in Table 3. Standard errors are reported beneath the coefficients. The symbols ${ }^{* * *},{ }^{* *}$, and ${ }^{*}$ denote statistical significance at 1,5 , and $10 \%$, respectively.

rise per tax instrument. The semi-elasticities corresponding to the models in Table 4 (which includes the benchmark Model (2) from Table 3) are summarized in Table $5 .^{18}$

\footnotetext{
${ }^{18}$ To calculate the semi-elasticity of a log-transformed tax variable $t$, we raise $t$ by one percentage point, i.e., by 0.01 . In the model, this changes $\ln (1-t)$ to $\ln (1-t-0.01)$. Then, evaluated at the average, we consider the change in the probability of the average country to be chosen as a headquarters location in percent.
} 
Table 5 Baseline semi-elasticities_conditional logit

\begin{tabular}{lllllc}
\hline & LabTax & Prog500 & EmployerSocSec & EmployeeSocSec & CorpTax \\
\hline Stock of firms & $-0.017^{* * *}$ & $-0.009^{* * *}$ & $-0.055^{* * *}$ & $-0.022^{* * *}$ & $-0.010^{* * *}$ \\
Relocating firms & $-0.082^{* * *}$ & $-0.068^{* * *}$ & $-0.122^{* * *}$ & $0.038^{*}$ & $-0.029^{* *}$ \\
Relocating \& new firms & $-0.061^{* * *}$ & $-0.064^{* * *}$ & $-0.068^{* * *}$ & $0.023^{* *}$ & $-0.030^{* * *}$ \\
\hline
\end{tabular}

Notes: The average semi-elasticities refer to Table 4 . The symbols ${ }^{* * *},{ }^{* *}$, and ${ }^{*}$ denote statistical significance at 1,5 , and $10 \%$, respectively.

One-hundred times an entry in Table 5 indicates the percentage change in the average country's probability of being chosen as a headquarters location in response to a one-percentage point increase in a respective tax instrument at a time. The results suggest that a one-percentage point increase in the employer-borne social security contributions exhibits the relatively biggest effect among the instruments considered. In most specifications, this is followed by the wage tax rate. The relatively lowest results are recorded for corporate income taxes. We argue that this result can be ascribed to the possibility of corporate profit shifting to low tax locations. In comparison, the income tax base (wage bill) cannot be as easily manipulated as the profit tax base, which leads to relatively bigger effects of labor income taxes and social security contributions on the location choice than of profit taxes.

\subsection{Nested logit estimates}

For the reasons explained in Sect. 3.2, it may be worthwhile to consider a nested logit model as an alternative econometric approach towards headquarters location choice. Table 6 reports the results for a nested logit model based on the specification of Model (2) in Table 3 and using different nesting approaches. We use the nest-averaged log of GDP per capita for each nest as the nest-specific variable, $w_{n}$, in terms of Eq. (5). As in the conditional logit specification, the coefficients on

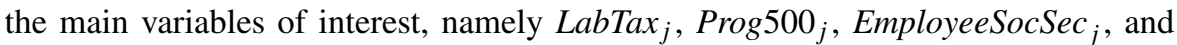
EmployerSocSec $_{j}$ are all positive and highly significant in the model with income nesting.

As alternatives to income nesting, we employ three different types of nesting based on geographical variables. In the second column of Table 6, we group countries into continental groups: the Americas (comprised of countries in North America, Latin America, and the Caribbean), Europe (comprised of European countries, including Russia), and the Rest of the World (comprising all remaining countries in Africa, Asia, and Oceania). As before, the coefficients on all main variables of interest are positive and highly significant, while the corporate tax variable is insignificant. ${ }^{19}$

\footnotetext{
${ }^{19}$ These results are in line with Strauss-Kahn and Vives (2009) who also find low elasticities for the corporate tax. In their study, corporate tax levels are insignificant in a region-nested model but have a significant impact on the headquarters location choice in a population-nested model. In their populationnested specifications, a one percentage point rise in the corporate tax rate reduces the probability of a state as a headquarters location by $2.25 \%$. As Strauss-Kahn and Vives (2009) also note, these lower elasticities
} 
Table 6 Baseline regression results: nested logit models

\begin{tabular}{|c|c|c|c|c|}
\hline & Income nested & Region nested & Distance nested & $\begin{array}{l}\text { Distance nested } \\
\text { (alternative) }\end{array}$ \\
\hline \multirow[t]{2}{*}{$\ln (1-$ LabTax $)$} & $3.849^{* * *}$ & $1.913^{* * *}$ & $1.039^{* * *}$ & $0.862^{* * *}$ \\
\hline & 0.770 & 0.322 & 0.250 & 0.194 \\
\hline \multirow[t]{2}{*}{$\ln (1-$ Prog 500$)$} & $2.368^{* * *}$ & $1.056^{* * *}$ & $0.614^{* * *}$ & $0.581^{* * *}$ \\
\hline & 0.477 & 0.179 & 0.144 & 0.124 \\
\hline \multirow[t]{2}{*}{$\ln (1-$ EmployerSocSec $)$} & $6.461^{* * *}$ & $3.916^{* * *}$ & $4.074^{* * *}$ & $2.776^{* * *}$ \\
\hline & 1.245 & 0.569 & 0.571 & 0.505 \\
\hline \multirow[t]{2}{*}{$\ln (1-$ EmployeeSocSec $)$} & $1.687^{* * *}$ & $1.472^{* * *}$ & $2.149^{* * *}$ & $1.211^{* * *}$ \\
\hline & 0.383 & 0.256 & 0.336 & 0.243 \\
\hline \multirow[t]{2}{*}{$\ln (1-\operatorname{CorpTax})$} & $0.781^{* * *}$ & 0.064 & $0.884^{* * *}$ & $0.657^{* * *}$ \\
\hline & 0.229 & 0.147 & 0.202 & 0.156 \\
\hline \multirow[t]{2}{*}{$\ln (G D P)$} & 0.229 & $1.805^{* * *}$ & $1.484^{* * *}$ & $0.843^{* * *}$ \\
\hline & 0.144 & 0.275 & 0.223 & 0.166 \\
\hline \multirow[t]{2}{*}{$\ln ($ CapStock $)$} & $4.221^{* * *}$ & $1.365^{* * *}$ & $1.092^{* * *}$ & $1.262^{* * *}$ \\
\hline & 0.820 & 0.230 & 0.190 & 0.240 \\
\hline \multirow[t]{2}{*}{$\ln ($ Wage $)$} & $-3.379^{* * *}$ & $0.897^{* * *}$ & $0.996^{* * *}$ & $0.520^{* * *}$ \\
\hline & 0.701 & 0.200 & 0.200 & 0.135 \\
\hline \multirow[t]{2}{*}{$\ln (T e r t E d u)$} & $4.571^{* * *}$ & $2.042^{* * *}$ & $0.892^{* * *}$ & $1.141^{* * *}$ \\
\hline & 0.917 & 0.378 & 0.283 & 0.267 \\
\hline \multirow[t]{2}{*}{ LegalRights $_{\text {Dummy }}$} & $0.709^{* * *}$ & $0.504^{* * *}$ & $0.859^{* * *}$ & $0.424^{* * *}$ \\
\hline & 0.139 & 0.075 & 0.120 & 0.078 \\
\hline \multirow[t]{2}{*}{$\ln ($ Wage $\times$ TertEdu $)$} & $-0.477^{* * *}$ & $-0.222^{* * *}$ & $-0.150^{* * *}$ & $-0.143^{* * *}$ \\
\hline & 0.096 & 0.040 & 0.033 & 0.031 \\
\hline \multirow[t]{2}{*}{$\ln ($ CapStock $\times G D P)$} & $-0.086^{*}$ & $-0.037^{* * *}$ & $-0.024^{* * *}$ & $-0.024^{* * *}$ \\
\hline & 0.017 & 0.006 & 0.005 & 0.005 \\
\hline \multirow[t]{2}{*}{$\ln ($ Wage $\times G D P)$} & $0.137^{* * *}$ & $-0.029^{* * *}$ & $-0.034^{* * *}$ & $-0.018^{* * *}$ \\
\hline & 0.028 & 0.007 & 0.007 & 0.005 \\
\hline Cases & 35,206 & 35,206 & 35,206 & 35,206 \\
\hline Log-likelihood & $-113,308.44$ & $-112,375.74$ & $-112,785.34$ & $113,071.27$ \\
\hline LR test for IIA & $269.42^{* * *}$ & $640.80^{* * *}$ & $281.92^{* * *}$ & $814.02^{* * *}$ \\
\hline IIA passed? & Yes & Yes & Yes & Yes \\
\hline
\end{tabular}

Notes: Representation of nested logit results for baseline Model (2) as in Table 3. Standard errors are reported beneath the coefficients. The symbols ${ }^{* * *},{ }^{* *}$, and ${ }^{*}$ denote statistical significance at 1,5 , and $10 \%$, respectively.

As two further alternatives to income nesting, we group countries according to their average distance to the rest of the world in two ways. The first distance-based

compared to other studies can also be explained by the fact that these studies focus on manufacturing firms which creates an upward bias in the corporate tax effect whereas Strauss-Kahn and Vives (2009) and we use data on headquarters in all economic sectors. 
Table 7 Baseline semi-elasticities-nested logit

\begin{tabular}{|c|c|c|c|c|c|c|}
\hline & & LabTax & Prog500 & EmployerSocSec & EmployeeSocSec & CorpTax \\
\hline \multirow{4}{*}{$\begin{array}{l}\text { Income } \\
\text { nested }\end{array}$} & Mean & $-0.036^{* * *}$ & $-0.023^{* * *}$ & $-0.064^{* * *}$ & $-0.016^{* * *}$ & $-0.009^{* * *}$ \\
\hline & High-income & -0.028 & -0.018 & -0.049 & -0.012 & -0.007 \\
\hline & Middle-income & -0.044 & -0.029 & -0.080 & -0.020 & -0.012 \\
\hline & Low-income & -0.044 & -0.027 & -0.072 & -0.018 & -0.012 \\
\hline \multirow{4}{*}{$\begin{array}{l}\text { Region } \\
\text { nested }\end{array}$} & Mean & $-0.022^{* * *}$ & $-0.012^{* * *}$ & $-0.046^{* * *}$ & $-0.016^{* * *}$ & -0.001 \\
\hline & Americas & -0.020 & -0.012 & -0.046 & -0.016 & -0.001 \\
\hline & Europe & -0.026 & -0.015 & -0.057 & -0.020 & -0.001 \\
\hline & ROW & -0.018 & -0.010 & -0.036 & -0.013 & -0.001 \\
\hline \multirow{4}{*}{$\begin{array}{l}\text { Distance } \\
\text { nested }\end{array}$} & Mean & $-0.011^{* * *}$ & $-0.007^{* * *}$ & $-0.045^{* * *}$ & $-0.022^{* * *}$ & $-0.012^{* * *}$ \\
\hline & Near & -0.013 & -0.008 & -0.053 & -0.025 & -0.013 \\
\hline & Middle & -0.011 & -0.007 & -0.041 & -0.021 & -0.012 \\
\hline & Far & -0.009 & -0.006 & -0.038 & -0.019 & -0.010 \\
\hline \multirow{4}{*}{$\begin{array}{l}\text { Distance } \\
\text { nested } \\
\text { (alterna- } \\
\text { tive) }\end{array}$} & Mean & $-0.014^{* * *}$ & $-0.010^{* * *}$ & $-0.047^{* * *}$ & $-0.019^{* * *}$ & $-0.013^{* * *}$ \\
\hline & Near & -0.016 & -0.011 & -0.055 & -0.022 & -0.015 \\
\hline & Middle & -0.011 & -0.008 & -0.035 & -0.014 & -0.011 \\
\hline & Far & -0.012 & -0.008 & -0.038 & -0.017 & -0.012 \\
\hline
\end{tabular}

Notes: The average semi-elasticities refer to Table 6 . The symbols ${ }^{* * *},{ }^{* *}$, and ${ }^{*}$ denote statistical significance at 1,5 , and $10 \%$, respectively.

nesting summarized in the third column of Table 6 groups countries with an average distance of less than 7,000 km into the category Near, an average distance to the rest of the world between 7,000 km and 9,000 km into the category Middle, and all remaining countries into the category Far. The second distance-based nesting summarized in the fourth column of Table 6 (denoted Alternative), draws those boundaries at $8,000 \mathrm{~km}$ and $10,000 \mathrm{~km}$, respectively. ${ }^{20}$ Also with distance-based nesting, the coefficients of the variables of interest, namely the ones involving $\operatorname{LabTax}_{j}, \operatorname{Prog}_{500}$, EmployerSocSec $_{j}$, and EmployeeSocSec ${ }_{j}$, are positive and highly significant.

Table 7 summarizes the semi-elasticities of location choice with respect to tax instruments corresponding to the parameter estimates in Table 6. The magnitudes of those semi-elasticities are generally comparable to the ones based on the conditional logit models in Table 5.

\subsection{Sensitivity analysis and further results}

In the sensitivity analysis, we focus on conditional logit models since they are comparable regarding the semi-elasticities and much less demanding in terms of likelihood optimization. Since the semi-elasticities are more meaningful than mere parameter estimates, we focus on a presentation of those.

\footnotetext{
${ }^{20}$ The average distance to the rest of the world ranges from a little more than $6,500 \mathrm{~km}$ for Bulgaria to over $13,000 \mathrm{~km}$ for New Zealand.
} 
We summarize the sensitivity analysis in Table 8 . The table is organized horizontally in three blocks and vertically in two blocks. Horizontally, we distinguish between samples of all firms 35,206 firms in 2005-2009 and their location choice independent of the time (Stock of Firms; far left), of all 610 firms relocating between 1992 and 2009 (Relocating Firms; in the center), and of all 4,335 first-locating or relocating firms between 1992 and 2009 (Relocating \& New Firms; far right).

Vertically, we report on three robustness checks using subsamples in the upper part of the table and on the use of one alternative tax instrument in the last row of Table 8. In two robustness checks presented in the first two lines of Table 8, we restrict the sample to high-skilled and low-skilled intensive firms, respectively. Such firms are identified by a ratio of expenditures on research and development and sales which is higher than the median and low-skilled intensive firms by a ratio which is at most as high as the median. In a third experiment, we focus on a sample, which excludes holding companies. The Compustat North American database-which is a sub-set of the data used here-includes data on so-called American Depositary Receipt (ADR) companies, which are basically US holding companies. We are able to use this information to exclude these companies.

In the fourth row of Table 8, which represents an experiment involving an alternative tax instrument, we replace the tax progressivity measure, Prog500 $j$, by the labor tax rate on five times the average wage in a country, LabTax $500_{j}$. The findings suggest that the qualitative insights from earlier tables are unchanged. In particular, employer-borne social security contributions are relatively important among the considered instruments, and several labor tax instruments exhibit higher semi-elasticities as corporate taxes do for headquarters location. The tax rate for five times the average wage, LabTax $500_{j}$, exhibits a significant negative impact on top of the income tax rate for the average wage. This is consistent with the results involving tax progressivity in Model (2) of Table 3.

\section{Conclusion}

This paper provides evidence on the impact of different components of effective labor taxes on the international location decision of firms' headquarters using data on 35,026 firms' headquarters and 79 countries. We compile a unique data set on effective labor income taxes comprising besides labor taxes also both employee-borne and employer-borne social security contributions as well as further country specific regulations. We merge these tax data with data from Compustat that provide information on the location of firms' headquarters and data from WDI on country specific characteristics. The richness of our tax data and the large number of firm headquarters observations as well as the econometric specifications employed allow a more precise identification of the impact of effective labor taxes on firms headquarters' location than aggregate data would.

Overall, our findings suggest that the progressivity of a country's tax schedule, the social security contributions levied and the level of the labor income tax affect the conditional probability of firms' headquarters location choice. The results are most pronounced for employer-borne payroll taxes. Hence, a one percentage point increase 


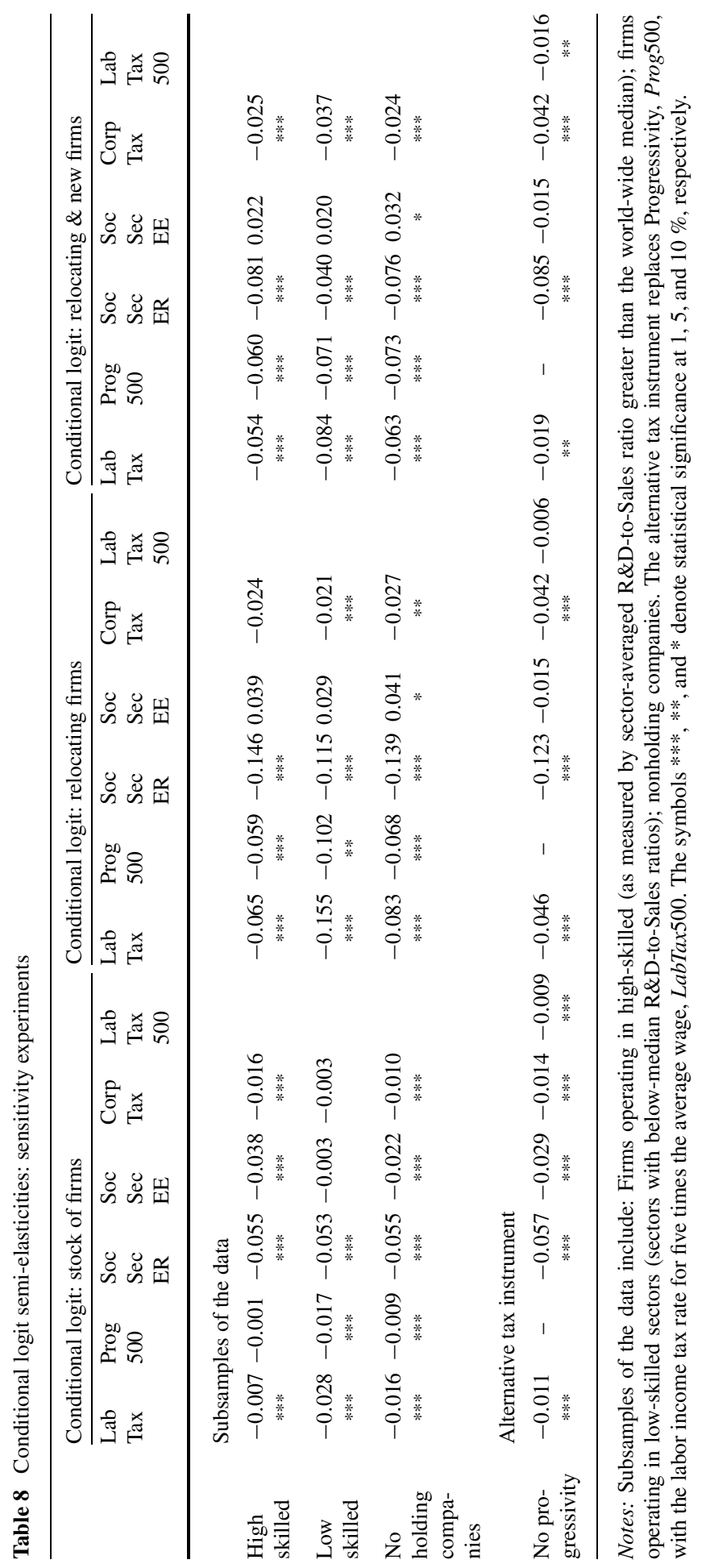


in a country's labor income tax leads — on average — to a reduction in the probability of a country as a potential location for headquarters by $1.7 \%$ in the whole stock of firms and by $6.1 \%$ for relocating and new firms, and 8.2 for relocating firms only. For employer social security contributions, the results are even larger and a one percentage point increase reduces the probability of headquarters' location by $5.5 \%$ in the whole sample of firms, by $6.8 \%$ when we consider only relocating and new firms, and by $12.2 \%$ if we focus on relocating firms only. The results prove robust in various empirical model specifications (such as using alternative nesting structures) and subsets of the data (i.e., focusing on firms operating in high or low skilled sectors only).

Acknowledgements The authors gratefully acknowledge funding from the Swiss Science Foundation through grant number 100014_131878. The authors would like to thank numerous comments by conference participants and discussants at the ETPF, IIPF, ESEM, CESifo Conference on Public Sector Economics, Public Choice Societies Congress, SSES, Verein für Socialpolitik, Doctoral Meeting of the Center for Business Taxation. In particular, the authors are grateful to an anonymous reviewer for numerous helpful comments.

\section{References}

Alesina, A., \& Perotti, R. (1994). The welfare state and competitiveness. NBER Working Paper, 4810.

Allison, P. D. (2009). Fixed effects regression models. Thousand Oaks: SAGE.

Arpaia, A., \& Carone, G. (2004). European economy-economic papers: Vol. 216. Do labour taxes (and their composition) affect wages in the short and the long run? Brussels: Directorate General Economic and Monetary Affairs (DG ECFIN), European Commission.

Baldwin, R. E., Forslid, R., Martin, P., Ottaviano, G., \& Robert-Nicoud, F. (2003). Economic geography and public policy. Princeton: Princeton University Press.

Barba Navaretti, G., \& Venables, A. J. (2006). Multinational firms in the world economy. Princeton: Princeton University Press.

Becker, S. O., Ekholm, K., Jäckle, R., \& Muendler, M.-A. (2005). Location choice and employment decisions: a comparison of German and Swedish multinationals. Review of World Economics, 141(4), 693-731.

Bel, G., \& Fageda, X. (2008). Getting there fast: globalization, intercontinental flights and location of headquarters. Journal of Economic Geography, 8(4), 471-495.

Büttner, T., \& Wamser, G. (2007). Intercompany loans and profit shifting-evidence from company-level data. In CESifo working paper series (Vol. 1959).

Carr, D. L., Markusen, J. R., \& Maskus, K. (2001). Estimating the knowledge-capital model of the multinational enterprise. The American Economic Review, 91(3), 693-708.

Chiswick, B. (1999). Are immigrants favorably self-selected? The American Economic Review, 89(2), 181-185.

Chun, H., Kim, J.-W., Morck, R., \& Yeung, B. (2008). Creative destruction and firm-specific performance heterogeneity. Journal of Financial Economics, 89, 109-135.

Clausing, K. A. (2003). Tax-motivated transfer pricing and U.S. intrafirm trade prices. Journal of Public Economics, 87(9-10), 2207-2223.

Daveri, F., \& Tabellini, G. (2000). Unemployment growth and taxation in industrial countries. Economic Policy, 30, 47-88.

Davis, J. C., \& Henderson, J. V. (2008). The agglomeration of headquarters. Regional Science and Urban Economics, 38(5), 445-460.

Defever, F. (2006). Functional fragmentation and the location of multinational firms in the enlarged Europe. Regional Science and Urban Economics, 36(5), 658-677.

Devereux, M., \& Hubbard, G. (2003). Taxing multinationals. International Tax and Public Finance, 10(4), 469-487.

Devereux, M., \& Griffith, R. (1998). Taxes and the location of production: evidence from a panel of U.S. multinationals. Journal of Public Economics, 68(3), 335-367. 
Dischinger, M., \& Riedel, N. (2011). Corporate taxes and the location of intangible assets within multinational firms. Journal of Public Economics, 95(7-8), 691-707.

Duffy, J., Papageorgiou, C., \& Perez-Sebastian, F. (2004). Capital-skill complementarity? Evidence from a panel of countries. Review of Economics and Statistics, 86(1), 327-344.

Egger, P., \& Radulescu, D. (2011). Labor taxation and foreign direct investment. Scandinavian Journal of Economics, 113(3), 603-636.

Fama, E. F., \& French, K. R. (2004). New lists: fundamentals and survival rates. Journal of Financial Economics, 73, 229-269.

Global legal information network, Law database (1980-2012). U.S. Library of Congress.

Goerke, L. (2000). The wedge. Manchester School, 68(5), 608-623.

Griliches, Z. (1980). R \& D and the productivity slowdown. American Review of Economics, 70(4), 343348.

Griliches, Z. (1969). Capital-skill complementarity. Review of Economics and Statistics, 51, 465-468.

Greene, W. H. (2002). Econometric analysis (5th ed.). Englewood Cliffs: Prentice Hall International.

Grogger, J., \& Hanson, G. H. (2008). Income maximization and the selection and sorting of international migrants. In NBER working paper (Vol. 13821).

Handelsblatt (2009). Großunternehmen wandern in die Schweiz ab. Handelsblatt, 14.07.2009.

Head, K., \& Mayer, T. (2004). Market potential and the location of Japanese investment in the European Union. Review of Economics and Statistics, 86(4), 959-972.

Hines, J. R., \& Rice, E. M. (1994). Fiscal paradise: foreign tax havens and American business. The Quarterly Journal of Economics, 109(1), 149-182.

Huizinga, H., \& Laeven, L. (2008). International profit shifting within multinationals: a multi-country perspective. Journal of Public Economics, 92(5-6), 1164-1182.

International Labor Organization. LABORSTA, Web. 2011-03-28.

IMF, Staff Country Reports, International Monetary Fund, 1980-2010.

Kugler, A., \& Kugler, M. (2009). Labor market effects of payroll taxes in developing countries: evidence from Colombia. Economic Development and Cultural Change, 57(2), 335-358.

Liebig, T., \& Sousa-Poza, A. (2004). Migration, self-selection and income inequality: an international analysis. Kyklos, 57(1), 125-145.

Lutz, W., Goujon, A., KC, S., \& Sanderson, W. (2007). Reconstruction of population by age, sex and level of educational attainment of 120 countries for 1970-2000. In Vienna yearbook of population research 2007 (pp. 193-235).

Markusen, J. R. (2002). Multinational firms and the theory of international trade. Cambridge: MIT Press.

McFadden, D. (1974). Conditional logit analysis of qualitative choice behavior. In P. Zarembka (Ed.), Frontiers in econometrics (pp. 105-142). New York: Academic Press.

Mintz, J., \& Smart, M. (2004). Income shifting, investment, and tax competition: theory and evidence from provincial taxation in Canada. Journal of Public Economics, 88(6), 1149-1168.

OECD (1990). Employer versus employee taxation: the impact on employment, in OECD. In OECD employment outlook 1990 (pp. 153-177).

OECD (1999). Taxing wages. Paris: OECD Publishing. 1990-2009.

Pastor, L., \& Veronesi, P. (2003). Stock valuation and learning about profitability. The Journal of Finance, 58(5), 1749-1790.

Peter, K. S., Buttrick, S., \& Duncan, D. (2010). Global reform of personal income taxation, 1981-2005: evidence from 189 countries. National Tax Journal, 63(3), 447-478.

PKF International, Worldwide Tax Guide, PKF International, 2007-2010.

PricewaterhouseCoopers, LLP, Individual Taxes: Worldwide Summaries, New York: Wiley, 1997-2005.

PricewaterhouseCoopers, LLP, Worldwide Tax Summaries. Web. 2011-03-28.

Rathelot, R., \& Sillard, P. (2008). The importance of local corporate taxes in business location decisions: evidence from French micro data. The Economic Journal, 118(527), 499-514.

Rutkowski, J., \& Walewski, M. (2007). Taxation of labor. In C. Williamson Gray, T. Lane, \& A. Varoudakis (Eds.), Fiscal policy and economic growth: lessons for Eastern Europe and Asia (pp. 281-314). Washington: The World Bank.

Social Security Observatory, Social Security Programs Throughout the World, International Social Security Association (2002-2010).

Strauss-Kahn, V., \& Vives, X. (2009). Why and where do headquarters move? Regional Science and Urban Economics, 39(2), 168-186.

United Nations Statistics Division, National accounts estimates of main aggregates, Web. 2011-03-28.

Weichenrieder, A. (2009). Profit shifting in the EU: evidence from Germany. International Tax and Public Finance, 16(3), 281-297.

World Bank, World development indicators, Web. 2011-04-03. 